\title{
Expression of DNA methyltransferases in the mouse uterus during early pregnancy and susceptibility to dietary folate deficiency
}

\author{
Y B Ding, J L He, X Q Liu, X M Chen, C L Long and Y X Wang \\ Department of Reproductive Biology, Chongqing Medical University, Box 197, No. 1 Yixueyuan Road, \\ Chongqing 400016, People's Republic of China \\ Correspondence should be addressed to YX Wang; Email: wyx61221@yahoo.com.cn
}

\begin{abstract}
We have characterized the uterine expression of DNA methyltransferases (DNMTs) during early pregnancy in mice and determined whether a folate-deficient diet (FDD) can affect DNMTs in this context. Within endometrial cells, expressions of DNMT (cytosine-5) 1 (Dnmt1), Dnmt3a, and Dnmt3b were significantly elevated during the prereceptive phase of pregnancy but generally returned to baseline levels during receptive and postimplantation periods. As such, the transcription of DNMT genes is temporally regulated during early pregnancy. When comparisons were made between implantation sites (IS) and inter-IS on day 5 of pregnancy, lower levels of Dnmt3a were detected at IS. Comparisons between IS and inter-IS did not reveal significant expression differences for other DNMT genes. When tissue sections were examined, DNMT3A was specifically lower in the stroma of IS. Reduced DNMT1 and DNMT3B levels were also observed in the luminal and glandular epithelia of IS, whereas no obvious differences in the stroma were detected. In pseudopregnant mice subjected to a FDD, levels of Dnmt1 and Dnmt3a (but not Dnmt3b) were significantly upregulated in endometrial tissues, as compared with controls. When tissues from these folate-deficient mice were examined, DNMT1 levels were elevated in both the luminal and glandular epithelia, whereas DNMT3A was upregulated in the luminal epithelium and the stroma. A slight increase in DNMT3B levels was detected in the glandular epithelium. These results indicate that DNMTs may regulate the transcription of endometrial genes associated with embryo implantation and that levels of DNMTs are affected by dietary folate in mice.

Reproduction (2012) 144 91-100
\end{abstract}

\section{Introduction}

The methylation of the cytosine guanine dinucleotide (CpG) is an epigenetic modification that silences gene transcription and plays a critical role in cancer development and progression (Issa et al. 1994, Laird \& Jaenisch 1996). Three DNA methyltransferase (DNMT) enzymes catalyze DNA methylation. DNMT (cytosine-5) 1 (DNMT1) maintains methylation patterns during DNA replication, whereas DNMT3A and DNMT3B catalyze de novo DNA methylation (Okano et al. 1999, Robert et al. 2003). Altered levels of DNMTs can cause hyperand hypo-methylation, which are associated with downregulating and reactivating gene expression, respectively (Baylin et al. 1991, Kanai \& Hirohashi 2007, Morey Kinney et al. 2008).

Changes to the pattern of DNA methylation may functionally alter endometrial cells (Munro et al. 2010). For example, DNA methylation of the estrogen receptor 2 (ESR2) promoter downregulates ESR2 levels (both mRNA and protein) in endometrial stromal cells (Xue et al. 2007). The CpG-rich region within the homeobox A10 promoter is hypermethylated in the endometria of women who have intrauterine devices (Lu et al. 2010). Both prolactin and insulin-like growth factor-binding protein 1 are markers for decidualization and both are upregulated in human endometrial stromal cells after treatment with a demethylation agent (5'-aza-2'-deoxycytidine) (Logan et al. 2010). E-cadherin is regulated by DNA methylation during the establishment of a receptive endometrium in vitro (Rahnama et al. 2009). Finally, expression levels of DNMT1, DNMT3A, and DNMT3B are altered during the female menstrual cycle and are regulated by both progesterone and estrogen (Yamagata et al. 2009, Vincent et al. 2011). Taken together, these results strongly suggest that DNA methylation affects the endometrium, but very little is known about the roles played by DNMTs during early stages of pregnancy.

Folate is an important dietary vitamin, and its deficiency in humans is associated with several diseases (Botez et al. 1978, Kim 2005, Burren et al. 2008). Folate deprivation has also been implicated in early pregnancy loss (Ronnenberg et al. 2007) and recurrent spontaneous abortions (Sutterlin et al. 1997, George et al. 2002). 
Folate provides $S$-adenosylmethionine, the primary methyl donor for most methylation reactions, and thereby modulates DNA methylation in a wide range of biological contexts (Burdge \& Lillycrop 2010). Moderate depletion of folate results in the site-specific hypomethylation of tumor protein TP53 (p53) in endometriotic stromal cells (Wasson et al. 2006) and cyclin-dependent kinase inhibitor $2 \mathrm{a}(C D K N 2 A)$ in head and neck squamous cell carcinoma (Kraunz et al. 2006). Reduced levels of folate, however, also lead to genomic DNA hypermethylation (Kotsopoulos et al. 2008) and de novo methylation of $C d k n 2 a$ in adult rat liver and early preneoplastic liver (Pogribny \& James 2002). Despite these paradoxical results, folate clearly affects both DNA methylation and gene transcription within the associated genetic regions. Furthermore, levels of Dnmt1, Dnmt3a, and $D n m t 3 b$ are altered in the liver and serum of nonpregnant mice subjected to a folate-deficient diet (FDD) and in serum samples from women who have taken supplemental folate (Ghoshal et al. 2006, Piyathilake et al. 2008). We have examined, therefore, the expression of DNMTs in the uteruses of early pregnant mice and in the uteruses of pseudo-pregnant mice that were subjected to a FDD. We sought to determine whether the expression of DNMTs in the mouse uterus varies with respect to the time of embryo implantation during early pregnancy and whether those expression levels are susceptible to dietary folate deficiency.

\section{Results}

\section{DNMT gene expression levels in the mouse uterus} during early pregnancy

RNA samples were isolated from mice uteruses during the earliest stages of pregnancy. qPCR analysis was then used to quantify the expression levels of genes that encode DNMTs. Expression of Dnmt1 in endometria increased during the prereceptive phase of pregnancy from D1 to D3 (Fig. 1A). Expression gradually returned to baseline during the receptive phase and early postimplantation period (D4, D5, and D7). On D5 and D7, levels of Dnmt1 were not significantly different between implantation site (IS) and inter-IS. The temporal pattern of expression of Dnmt3a was similar to that of Dnmt1 (Fig. 1B). One major difference, however, is that on D5 significantly lower levels of Dnmt3a expression were detected at IS as compared with those at inter-IS. These values were still generally higher than those on D1 (Fig. 1B). Dnmt3b expression peaked on D3. From D4 to D7, Dnmt3b levels were dramatically reduced, dropping well below D1 levels. No differences in Dmnt3b expression were detected between IS and inter-IS on D5 and D7 (Fig. 1C).
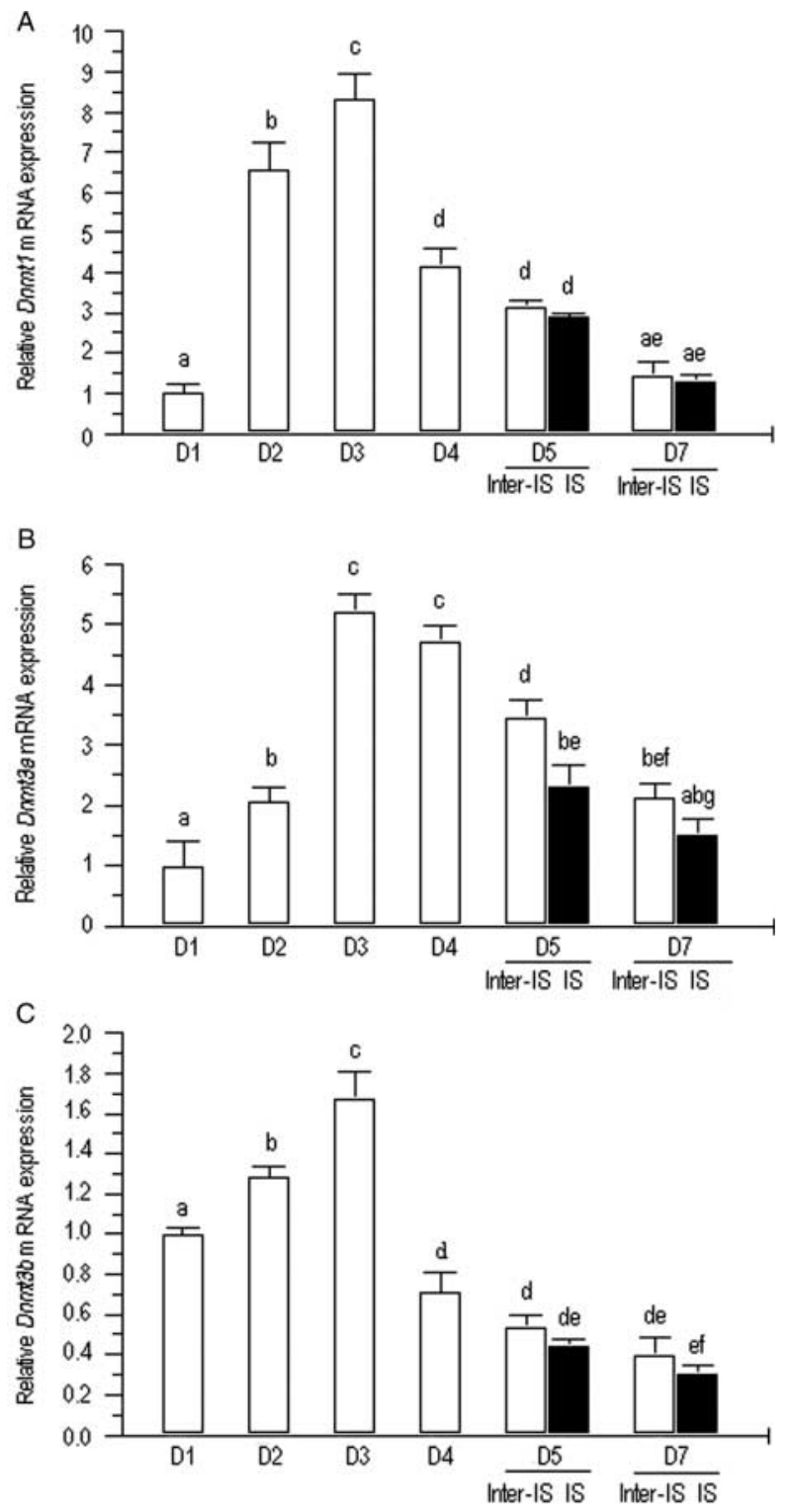

Figure 1 qPCR analysis of mRNA levels of DNA methyltransferases. Levels within the mouse endometrium during early pregnancy are shown for Dnmt1 (A), Dnmt3a (B), and Dnmt3b (C). Dnmt mRNA levels were normalized to Gapdh. Bars indicate the mean \pm s.D. Bars labeled with different lowercase letters indicate that the data are significantly different between groups ( $P<0.05 ; n=6$ per group).

\section{Western blot analysis of DNMT protein in the mouse uterus during early pregnancy}

On both D5 and D7, DNMT3A protein levels were significantly lower at IS compared with inter-IS $(P<0.01$ and $P<0.05$ respectively; Fig. 2B). Similar differences for DNMT1 and DNMT3B were not detected (Fig. 2A and C). At IS, protein levels for DNMT1 and DNMT3B were significantly lower on D7 than on D5 $(P<0.01$; Fig. 2). Similar differences for DNMT3A were not detected. In general, DNMT protein levels were lower on D7 than on D5. 
A

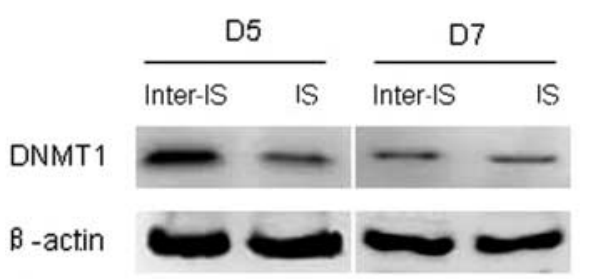

B
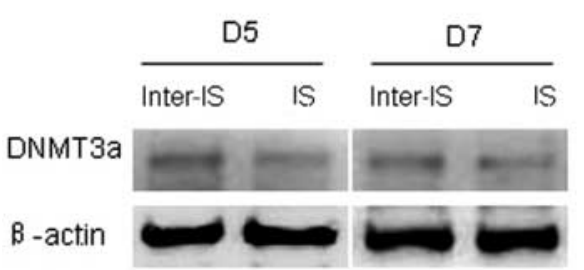

C
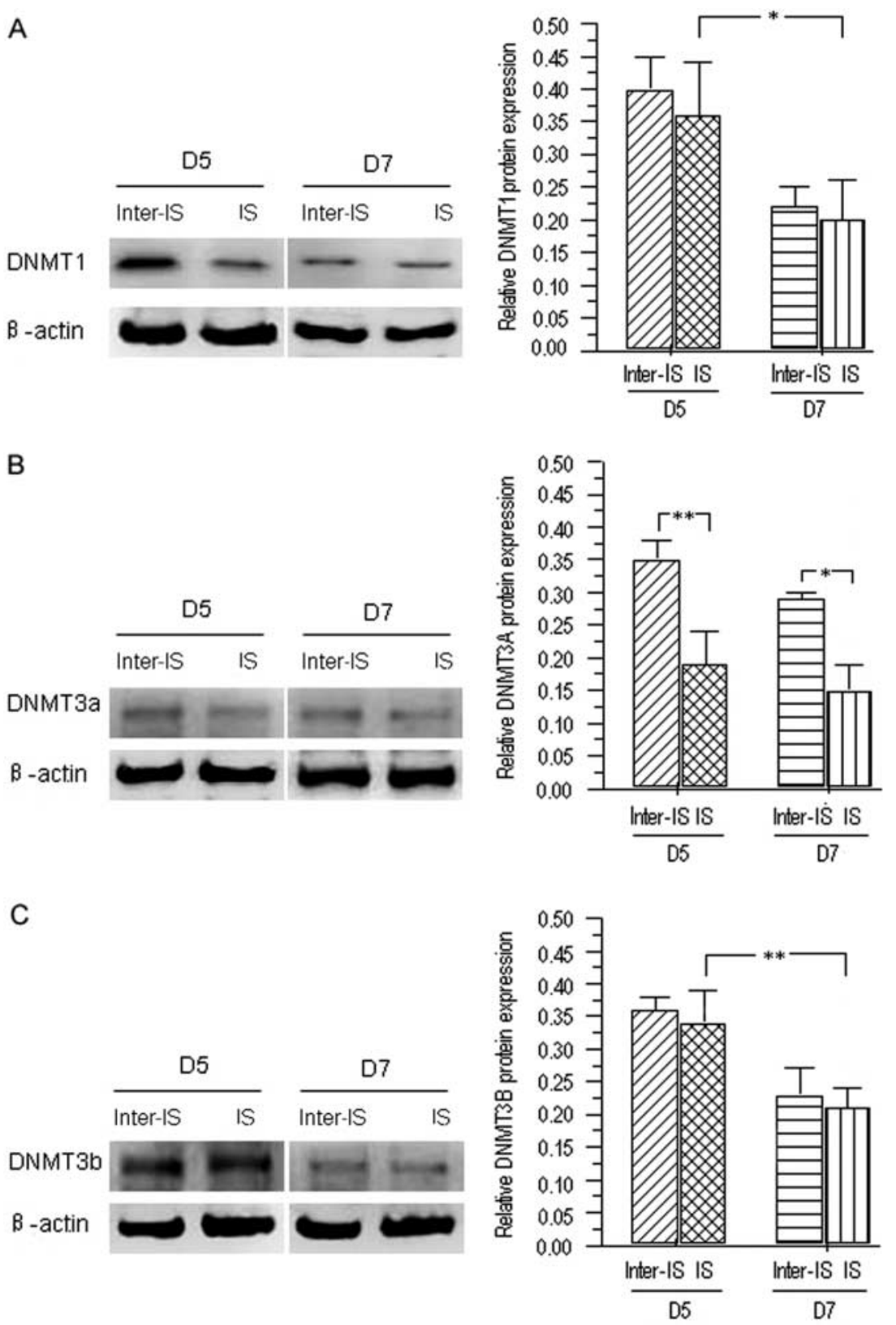

\section{DNMT immunohistochemistry in the mouse uterus during early pregnancy}

To determine whether DNMT protein levels are affected by implantation, we used immunohistochemistry to assess DNMT localization in the mouse uterus during early pregnancy. On D5, DNMT1-staining intensity at inter-IS was moderate in the stroma, the luminal epithelium, and the glandular epithelia. At IS, DNMT1 staining was moderate in the stroma, but no staining was detected in either the luminal or glandular epithelia. On D7, DNMT1 staining at inter-IS was weak in the stroma but was maintained at a moderate level in both the luminal and glandular epithelia. At IS, DNMT1 staining was weak in the stroma but was absent from both the luminal and glandular epithelia (Fig. 3 and Table 1).

DNMT3A localized exclusively to stromal cells, as staining was absent from both the luminal and glandular epithelia, regardless of the time point. On D5, DNMT3A staining was strong in the stroma at inter-IS but was greatly reduced at IS (Fig. 3 and Table 1). On D7, DNMT3A staining was still elevated in stromal cells at inter-IS compared with IS, but this difference was reduced as compared with that on D5 (Fig. 3 and Table 1). Thus, DNMT3A protein levels in stroma are associated with the time of embryo implantation. DNMT3A protein was absent or weak in luminal and 


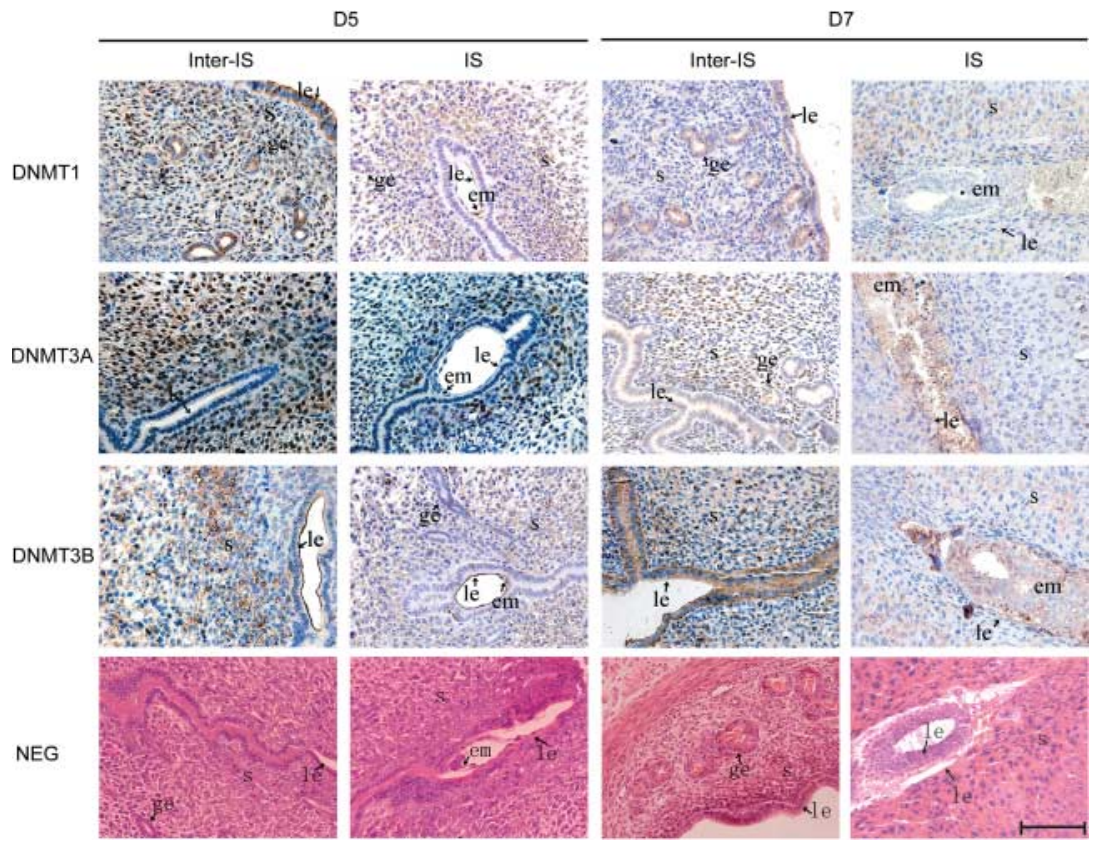

Figure 3 DNMT localization within uteruses of pregnant mice. DNMT1, DNMT3A, and DNMT3B expression at IS and Inter-IS at D5 and D7 of pregnancy is shown. On D5, DNMT1 staining intensity at Inter-IS was moderate in the stroma, le, and ge. At IS, DNMT1 staining was moderate in the stroma, but no staining was detected in either the le or ge. DNMT3A staining was strong in the stroma at Inter-IS but was greatly reduced at IS. DNMT3B staining at both IS and Inter-IS was moderate in the stroma, weak in the le, and absent from the ge. On D7, DNMT1 staining at Inter-IS was weak in the stroma but was maintained at a moderate level in both the le and ge. At IS, DNMT1 staining was weak in the stroma but absent from both the le and ge. DNMT3A staining was still elevated in stromal cells at Inter-IS as compared with IS. DNMT3B staining was reduced in all cell types with the exception of the le of Inter-IS, where protein levels were moderately elevated. The binding of antibodies to DNMT was detected as a brown precipitate using the streptavidin-biotin-immunoperoxidase method. Blue indicates an absence of DNMT expression. Sections that were not exposed to the primary antibody were used as negative controls (NEG). For detailed comparisons of staining intensities between groups, see Table 1. em, embryo; le, luminal epithelium; ge, glandular epithelium; s, stroma. Scale bar, $50 \mu \mathrm{m}$.

glandular epithelia of decidualized endometrium, with strong expression in undecidualized endometrium (data not shown).

On D5, DNMT3B staining at both IS and inter-IS was moderate in the stroma, weak in the luminal epithelium, and absent from the glandular epithelium (Fig. 3 and Table 1). On D7, DNMT3B staining was reduced in all cell types with the exception of the luminal epithelium at inter-IS, where protein levels were moderately elevated (Fig. 3 and Table 1).

\section{DNMT expression in uteruses of pseudo-pregnant mice fed with FDD}

To confirm the effect of the FDD on folate levels, six mice that had been fed the control diet were randomly selected for the determination of residual folate levels before the experimental groups were established. Folate levels did not vary significantly among these mice, and the average folate level for these mice was not significantly different from that of the pseudo-pregnant mice that were fed the control diet (data not shown).

Table 1 DNA methyltransferase (DNMT) expression in mouse uterine cells at inter-IS and IS during early pregnancy.

\begin{tabular}{|c|c|c|c|c|c|}
\hline Protein & Days of pregnancy & Region & Stroma & Luminal epithelium & Glandular epithelium \\
\hline \multirow[t]{4}{*}{ DNMT1 } & D5 & Inter-IS & ++ & ++ & ++ \\
\hline & & IS & ++ & - & \\
\hline & D7 & Inter-IS & + & ++ & ++ \\
\hline & & IS & + & - & - \\
\hline \multirow[t]{4}{*}{ DNMT3A } & D5 & Inter-IS & +++ & - & - \\
\hline & & IS & + & - & - \\
\hline & D7 & Inter-IS & ++ & - & - \\
\hline & & IS & + & - & - \\
\hline \multirow[t]{4}{*}{ DNMT3B } & D5 & Inter-IS & ++ & + & - \\
\hline & & IS & ++ & + & - \\
\hline & D7 & Inter-IS & + & ++ & - \\
\hline & & IS & + & - & - \\
\hline
\end{tabular}

- , no staining; + , weak; ++ , moderate staining; and +++ , strong staining. 


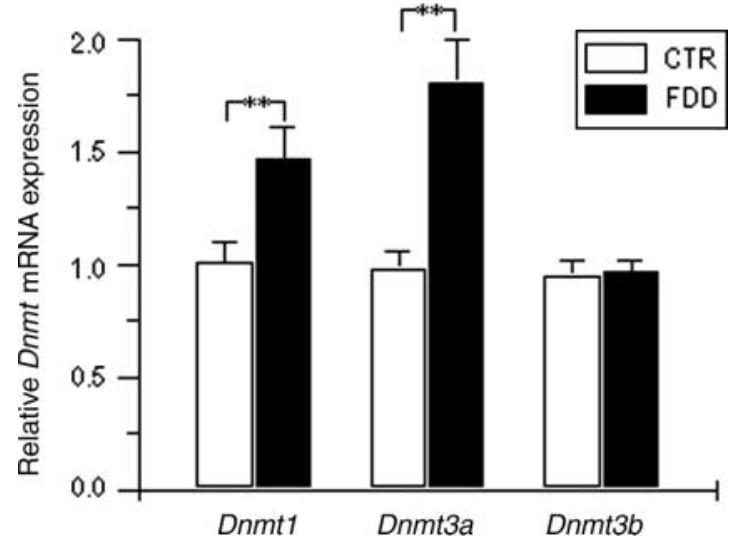

Figure 4 The effects of folate deficiency on Dnmt expression. qPCR analysis was used to determine mRNA levels of Dnmt genes in the endometrium of pseudo-pregnant mice subjected to a FDD. Dnmt mRNA levels were normalized to Gapdh ( $n=6$ per group). Bars indicate the mean \pm s.D. ${ }^{* *} P<0.01$ vs control (CTR; pseudo-pregnant mice that were fed a control diet).

Pseudo-pregnant mice subjected to a FDD, when compared with pseudo-pregnant mice that were fed the control diet, did, however, have significantly reduced levels of folate both in the liver $(2.93 \pm 0.38$ vs 12.63 $\pm 1.27 \mu \mathrm{g}$ folate/g respectively; $n=6, P<0.01)$ and serum $(2.41 \pm 0.42$ vs $15.33 \pm 2.14 \mathrm{ng}$ folate $/ \mathrm{ml}$ respectively; $n=6, P<0.01)$. In pseudo-pregnant mice with folate deficiencies, expression of both Dnmt1 $(P<0.01)$ and Dnmt3a $(P<0.01)$ was significantly elevated in the endometrium (D5 of pregnancy was analyzed). In contrast, no change was detected in Dnmt3b levels of expression ( $P=0.373$; Fig. 4). Western blot analysis confirmed these results (Fig. 5).

We next examined the tissue sections to determine whether the FDD affected DNMT expression in a cell type-specific fashion within the uterus. Compared with controls, mice fed with FDD had elevated levels of DNMT1 protein in the luminal and glandular epithelia, with no change observed in the stroma (Fig. 6 and Table 2). DNMT3A expression was slightly increased in the luminal epithelium and was dramatically elevated in the stroma of FDD-fed mice (Fig. 6 and Table 2). Finally, a FDD resulted in a slight increase in DNMT3B protein levels in the glandular epithelium (Fig. 6 and Table 2).

\section{Discussion}

Within human endometrial tissues, mRNA levels of DNMT1 and DNMT3A are lower during the secretory phase than the proliferative phase. In contrast, protein levels of DNMT1, DNMT3A, and DNMT3B do not change during the menstrual cycle (Yamagata et al. 2009). In agreement with this result, analyses of endometria during the early and late secretory menstrual phases detected lower levels of DNMT3A mRNA but no changes in DNMT protein levels (Vincent et al. 2011). Despite these discrepancies between DNMT mRNA and protein levels, results such as these suggest that the expression of DNMT-encoding genes is associated with endometrial changes during menstruation in humans. Correlations between DNMT expression and the DNA methylation of specific genes in the uterus during reproductive cycles, however, have not been sufficiently characterized.

Significantly higher DNA methylation levels have been detected in the proliferative phase when compared with the secretory phase in women (Ghabreau et al. 2004). In addition, both mRNA and protein levels of ESR2 are downregulated in the endometrial stromal cells by DNA methylation of the promoter (Xue et al. 2007). Similarly, both prolactin and insulin-like growth factorbinding protein 1, which are vital for decidualization, are upregulated in human endometrial stromal cells that have been treated with a demethylation agent $\left(5^{\prime}\right.$-aza- $2^{\prime}$ deoxycytidine) (Logan et al. 2010). However, it is unclear whether these genes are regulated by DNA methylation during the reproductive cycle or in association with embryo implantation.

Here we have examined mice uteruses during early stages of pregnancy to determine the levels of expression of genes that encode DNMTs. Transcript levels for all three DNMT genes peaked during the prereceptive phase of pregnancy (D3). Levels subsequently decreased back to baseline levels (or lower) during the receptive phase (D4 and D5) and the postimplantation period (D5 and D7). The maximum level of DNMT expression thus coincided with the period of steroid hormone dominance during early pregnancy in the mouse. As such, increased DNMT expression may be linked to active DNA methylation and to the downregulation of genes that generate a receptive endometrium. Decreased expression of DNMT genes during receptive and postimplantation phases could be associated with passive DNA demethylation, by increasing the expression of genes controlling endometrial cell
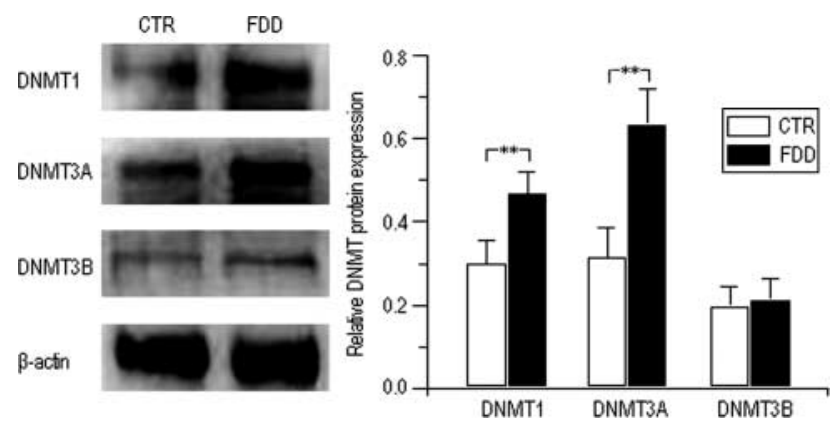

Figure 5 Western blot analysis of DNMT protein in the endometrium of pseudo-pregnant (PD5) mice fed a FDD. Data for DNMT1, DNMT3A, and DNMT3B are shown ( $n=6$ per group). Bars indicate the mean \pm s.D. from three independent experiments normalized to $\beta$-actin. ${ }^{* *} P<0.01$ vs control (CTR; pseudo-pregnant mice that were fed a control diet). 


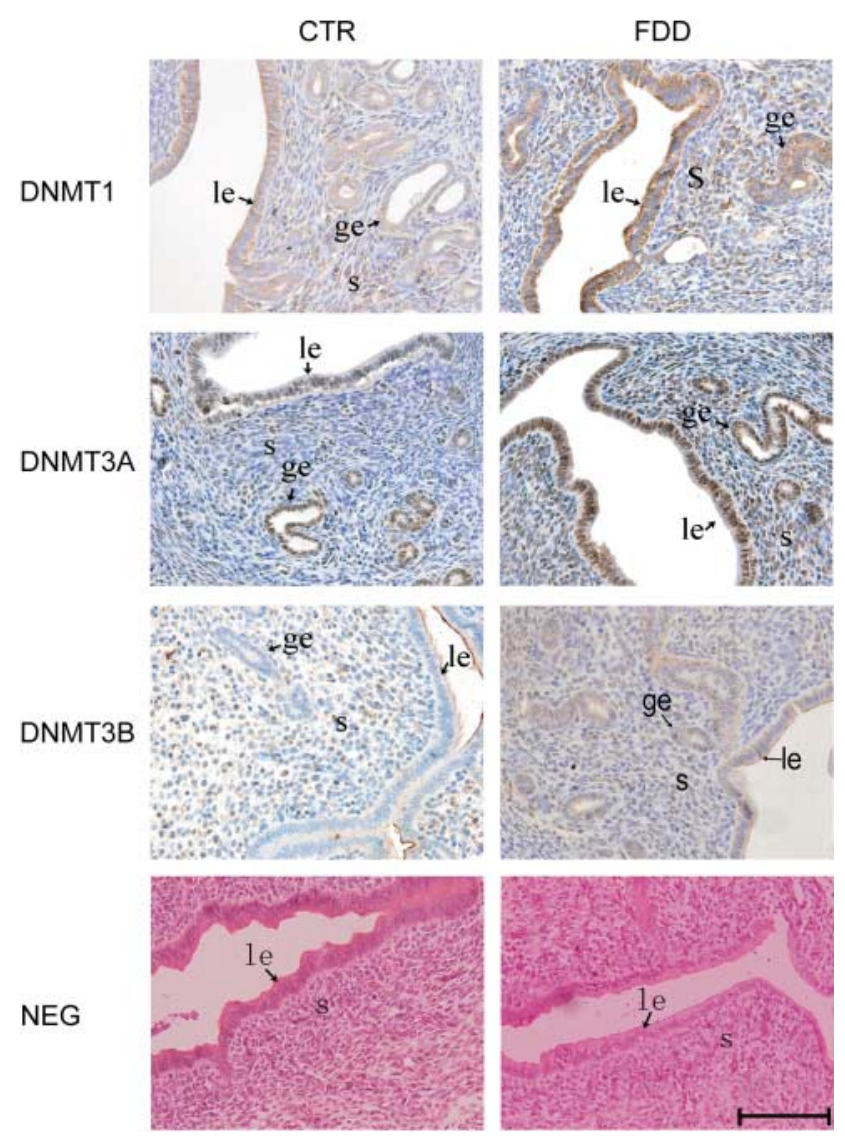

Figure 6 Protein localization patterns for DNMTs in endometria of pseudo-pregnant mice (PD5) fed either a control diet (CTR) or FDD. Immunostaining for DNMT1, DNMT3A, and DNMT3B is shown. DNMT was detected as a brown precipitate using the streptavidinbiotin-immunoperoxidase method. Blue indicates an absence of DNMT expression. Sections that were not exposed to the primary antibody were used as negative controls (NEG). For detailed comparisons of staining intensities between the groups, see Table 2 . em, embryo; le, luminal epithelium; ge, glandular epithelium; $\mathrm{s}$, stroma. Scale bar, $50 \mu \mathrm{m}$.

proliferation and differentiation (decidualization). Passive mechanisms of demethylation rely on DNA replication and the incorporation of unmethylated cytosines into new DNA strands, a process that does not require DNMT activity (Teperek-Tkacz et al. 2011). DNMTs play a dual role in the transcriptional cycling of ESR- $\alpha$ target genes by facilitating both the methylation and demethylation of these targets (Kangaspeska et al. 2008, Metivier et al. 2008). This supports the hypothesis that the DNA methylation status of the genome, or of a specific set of target genes, in the endometrium may vary during the reproductive cycle in mouse and human. In addition, growth arrest and DNA damage-inducible protein $\alpha$ (GADD45A), which is thought to be involved in active DNA demethylation (Barreto et al. 2007), is upregulated in human endometrium during the midsecretory phase (Tseng et al. 2010). In fact, many genes are downregulated in the mouse uterus during the prereceptive phase of pregnancy and are subsequently upregulated during receptive and implantation phases (Wang \& Dey 2006).

Here we have shown that both mRNA and protein levels of DNMT3A are significantly lower at IS than at Inter-IS on D5. As such, DNMT downregulation may be associated with embryo implantation, and Dnmt3a downregulation may play an important role in regulating the DNA methylation of genes that control implantation. To the best of our knowledge, no specific gene expression changes in the mammalian endometrium have been attributed to DNA methylation during implantation. Further experimentation is required to clarify this claim.

Previous studies have used immunohistochemistry to characterize the localization pattern of DNMT proteins within the human uterus. These proteins have been detected in endometrial stroma and epithelia during the proliferative phase but not the secretory phase (Liao et al. 2008). However, high levels of DNMT1, DNMT3A, and DNMT3B have also been detected during all menstrual phases (Yamagata et al. 2009). This discrepancy may have resulted from the isolation of different cell populations in the examined uterine tissue. Here we have evaluated the cell type-specific expression of DNMTs. At IS, DNMT staining was absent from the luminal epithelium on D5 and D7 of pregnancy (except for DNMT3B, which showed weak staining). In contrast, DNMTs were present (except for DNMT3A) in cells of the luminal epithelium at inter-IS. This suggests that DNA methylation may regulate, at least in part, genes that generate a receptive endometrium. Moreover, DNMT staining was mainly localized to the stroma at IS. Of note, DNMT3A levels were lower in stromal cells at IS than in stroma at inter-IS on both D5 and D7. Low levels of DNA methylation and subsequent transcriptional upregulation of genes at IS, therefore, may be associated with stromal cell differentiation during embryo implantation.

Recent evidence indicates that the expression of $D N M T 3 A$ and DNMT3B is regulated by estrogen and progesterone in the human endometrium, suggesting that female sex steroid hormones may affect DNA methylation. These steroids, which act in part through

Table 2 DNMT expression in uterus cells on D5 from pseudo-pregnant control mice (CTR) and mice fed with FDD.

\begin{tabular}{lllll}
\hline Protein & Treatment & Stroma & $\begin{array}{l}\text { Luminal } \\
\text { epithelium }\end{array}$ & $\begin{array}{l}\text { Glandular } \\
\text { epithelium }\end{array}$ \\
\hline DNMT1 & CTR & + & ++ & + \\
& FDD & + & +++ & ++ \\
DNMT3A & CTR & + & ++ & +++ \\
& FDD & +++ & +++ & +++ \\
DNMT3B & CTR & + & + & - \\
& FDD & + & + & + \\
\hline
\end{tabular}

- , no staining; + , weak; ++ , moderate staining; and +++ , strong staining. 
nuclear hormone receptors, are influenced by DNA methylation in the endometrium, myometrium, ovary, and breast (Piva et al. 1989, Lapidus et al. 1996, Hori et al. 2000, Ghabreau et al. 2004, Mehrotra et al. 2004, Ren et al. 2007, Suzuki et al. 2008, Li et al. 2010, Wei et al. 2012). These finding further suggest that the levels of DNMTs in endometrial tissues are regulated by estrogen and progesterone during menstruation.

Folate can also alter DNA methylation status (Pogribny \& James 2002, Kim 2005, Oommen et al. 2005, Kraunz et al. 2006, Wasson et al. 2006, Kotsopoulos et al. 2008). A folate- and methyl-deficient diet increases the expression of Dnmt1, Dnmt3a, and Dnmt3b in the livers of rats (Ghoshal et al. 2006), and folate fortification increases DNMT1 expression in the human cervix (Piyathilake et al. 2008). Interestingly, our study has shown that a FDD significantly upregulated DNMT1 and DNMT3A (both mRNA and protein) in the uteruses of pseudo-pregnant mice, suggesting that folate regulates DNMT expression. Furthermore, the DNA methylation status of the genes that control endometrial changes may be affected by folate levels. Further studies are required, however, to elucidate the molecular mechanisms by which DNMT levels are regulated during pregnancy and to determine which genes are specifically affected by folate deficiency.

\section{Materials and Methods}

\section{Animals and treatment}

This research plan was approved by the ethics committee of Chongqing Medical University (No. 20110016). Male and female white Kunming mice (8 weeks old, 20-24 g) were purchased from the Laboratory Animal Center of Chongqing Medical University (China). Before experiments were initiated, all mice were fed the same diet, which contained $2 \mathrm{mg}$ folate/kg (Research Diets, New Brunswick, NJ, USA) for 2 weeks. Six female mice were randomly selected to measure the residual folate levels. Six groups ( $n=8$ each) of randomly selected female mice were mated with fertile males and were used to measure the gene expression on days 1-7 of pregnancy; pregnant day 1 (D1) was the day when a vaginal plug was detected. Mice from an additional group $(n=8)$ were fed the control diet, which contained $2 \mathrm{mg}$ folate/kg, for 35 days and then were mated with vasectomized males to induce pseudo-pregnancy; pseudo-pregnant day 1 (PD1) was the day when a vaginal plug was detected. The folate-deficient group $(n=16)$ was fed a diet that lacked folate for 35 days (Research Diets; Walzem \& Clifford 1988, Bills et al. 1992, Kim et al. 1996, Kotsopoulos et al. 2005). These 16 mice were then mated with infertile males to induce pseudo-pregnancy as described above. Male mice were fed the control diet. To ensure that the diets for the mice were similar, only mice that became pregnant within 5 days of mating were selected for further experimentation. Mice were subjected to the FDD, therefore, for 40-45 days. For all groups of mice, serum and liver folate levels were measured by HPLC (Patring et al. 2005). Mean levels of folate were calculated in groups ( $n=6$ each) on D5 (or PD5). After the mice were killed, the uteruses were excised, and the endometrial tissues were finely separated. ISs were distinguished from inter-ISs using i.v. injection of Chicago Blue B solution (Paria et al. 1993). The left uteruses were embedded in paraffin or snap-frozen in liquid nitrogen.

\section{RNA isolation and quantitative real-time PCR (qPCR)}

Total RNA was extracted from endometrial tissues using the TRIZol method (Invitrogen). DNase-treated total RNA was converted to cDNA using the PrimeScript RT reagent kit (TaKaRa, Dalian, China). mRNA expression was evaluated using the iQ5 Real-Time PCR Detection System (Bio-Rad Laboratories) with SYBR Premix Ex Taq II (T TaKaRa). The primers (Table 3) were designed using Primer Premier v5.0 (Premier Biosoft, Palo Alto, CA, USA) and synthesized by Sangon Biotechnology (Shanghai, China). qPCR was carried out at $95^{\circ} \mathrm{C}$ for $10 \mathrm{~min}$, followed by 40 cycles at $95^{\circ} \mathrm{C}$ for $30 \mathrm{~s}$, $T_{\mathrm{m}}$ (Table 3) for $30 \mathrm{~s}$, and at $72{ }^{\circ} \mathrm{C}$ for $45 \mathrm{~s}$. PCR products were processed in triplicate, subjected to a melting curve analysis, and examined using an agarose gel to confirm their size. Relative mRNA expression was calculated using the $2^{-\Delta \Delta C_{t}}$ method, with Gapdh as the normalization control.

\section{Western blot analysis}

Protein was extracted from endometrial tissues using the Mouse/Rat Tissue Extract Protein Array Kit (Sigma-Aldrich). Samples were boiled in $5 \times$ SDS sample-loading buffer for $10 \mathrm{~min}$. Equal amounts of protein $(30 \mu \mathrm{g})$ were separated using $10 \%(\mathrm{w} / \mathrm{v})$ SDS-PAGE and transferred to nitrocellulose

Table 3 Primer sequences for mouse DNMT genes and Gapdh.

\begin{tabular}{|c|c|c|c|c|}
\hline Genes & Sequence $\left(5^{\prime} \rightarrow 3^{\prime}\right)$ & Accession no. ${ }^{a}$ & Size (bp) & $T_{\mathbf{m}}{ }^{\mathrm{b}}\left({ }^{\circ} \mathrm{C}\right)$ \\
\hline Dnmt1 & $\begin{array}{l}\text { F: GGGTCTCGTTCAGAGCTG } \\
\text { R: GCAGGAATTCATGCAGTAAG }\end{array}$ & NM_010066.4 & 201 & 60 \\
\hline Dnmt3a & $\begin{array}{l}\text { F: CCGCCTCTTCTTTGAGTTCTAC } \\
\text { R: AGATGTCCСТCTTGTCACTAACG }\end{array}$ & NM_007872.4 & 125 & 55 \\
\hline$D n m t 3 b$ & $\begin{array}{l}\text { F: ATGGAGATCAGGAGGGTATGGA } \\
\text { R: GTCGCTTGGAGGTGGCTTTC }\end{array}$ & NM_001122997.1 & 177 & 56 \\
\hline Gapdh & $\begin{array}{l}\text { F: TGCCCCCATGTTTGTGATG } \\
\text { R: TGTGGTCATGAGCCCTTCC }\end{array}$ & NM_00103792 & 249 & 60 \\
\hline
\end{tabular}

\footnotetext{
${ }^{\mathrm{a}}$ Accession numbers correspond to GenBank entries. ${ }^{\mathrm{b}}$ The melting temperature.
} 
membranes (Bio-Rad Laboratories). Membranes were incubated with blocking buffer at $37^{\circ} \mathrm{C}$ for $2 \mathrm{~h}$ and then with primary rabbit polyclonal antibodies against DNMT1, DNMT3A, DNMT3B, and $\beta$-actin at $4{ }^{\circ} \mathrm{C}$ overnight (each at 1:400; Santa Cruz Biotechnology, Santa Cruz, CA, USA). After washing, the blots were incubated for $1 \mathrm{~h}$ with HRP-conjugated anti-goat or -rabbit secondary antibodies (Zhongshan Goldenbridge, Beijing, China) in the blocking buffer. After additional washes, the immunoreactive bands were visualized using $\mathrm{ECL}$ reagents (Beyotime, Shanghai, China). Protein expression was normalized to that of $\beta$-actin. Densitometry was performed using Quantity One v4.4.0 (Bio-Rad Laboratories).

\section{Immunohistochemistry}

Uteruses were fixed in $4 \%(\mathrm{w} / \mathrm{v})$ paraformaldehyde and embedded in paraffin wax. After deparaffinization and dehydration in a graded series of xylene and alcohol, sections were boiled for $15 \mathrm{~min}$ in $0.01 \mathrm{M}$ sodium citrate buffer for antigen retrieval. After cooling in the buffer for $60 \mathrm{~min}$ at room temperature, sections were incubated with $0.3 \%(\mathrm{v} / \mathrm{v}) \mathrm{H}_{2} \mathrm{O}_{2}$ / methanol for $30 \mathrm{~min}$. After three washes in PBS with $0.1 \%(\mathrm{v} / \mathrm{v})$ Tween 20 (PBST), sections were incubated with 5\% (v/v) normal rabbit serum in PBST to block nonspecific staining at room temperature for $30 \mathrm{~min}$. Sections were then incubated with primary rabbit polyclonal antibodies against DNMT1, DNMT3A, or DNMT3B (each at $1: 200$ ) at $4{ }^{\circ} \mathrm{C}$ overnight. Secondary antibodies were visualized using the avidin-biotin method (Zhongshan Goldenbridge) followed by washing. After incubation with tetrahydrochloride (Zhongshan Goldenbridge), sections were counterstained with hematoxylin. Negative control sections were processed with nonimmune serum (Zhongshan Goldenbridge) instead of the primary antibody and counterstained with hematoxylin and eosin. Image-Pro Plus (Media Cybernetics, Bethesda, MD, USA) was used to quantify images. The intensity of DNMT staining was classified as no staining $(-)$, weak staining $(+)$, moderate staining $(++)$, or strong staining $(+++)$.

\section{Statistical analysis}

SPSS v 11.5 (SPSS, Inc., Chicago, IL, USA) was used for the analyses. Data are described as mean \pm s.D. The uterine or endometrial samples from six pregnant (or pseudo-pregnant) mice in each group were analyzed. Western blot and qPCR analyses were independently repeated three times for each group. Differences between two groups were analyzed using the Student's $t$-test. Differences between three or more groups were analyzed using a one-way ANOVA. Post hoc comparisons between groups involved Fisher's protected least significant difference test. Results were considered statistically significant for $P<0.05$.

\section{Declaration of interest}

The authors declare that there is no conflict of interest that could be perceived as prejudicing the impartiality of the research reported.

\section{Funding}

This study was supported by the National Natural Science Foundation of China (no. 30700898), the Natural Science Foundation Project of CQ CSTC (nos. 2009BA5082, 2009BB5271, and 2011jjA10085), and the Excellent Doctoral Dissertation of Chongqing Medical University award. The funders had no role in the design of this study, data collection and analysis, the decision to publish, or the preparation of the manuscript.

\section{Author contribution statement}

$\mathrm{Y} B$ Ding and $\mathrm{Y} X$ Wang conceived and designed the experiments; $\mathrm{C} L$ Long and $\mathrm{Y}$ B Ding performed the experiments; Y B Ding, C L Long, J L He, and X M Chen contributed reagents, materials, and analysis; $Y$ B Ding wrote the paper.

\section{Acknowledgments}

The authors thank Prof. Xiaoqiu Xiao for suggestions and Vice Prof. Qing Zeng for his help with statistical analysis.

\section{References}

Barreto G, Schafer A, Marhold J, Stach D, Swaminathan SK, Handa V, Doderlein G, Maltry N, Wu W, Lyko F et al. 2007 Gadd45a promotes epigenetic gene activation by repair-mediated DNA demethylation. Nature 445 671-675. (doi:10.1038/nature05515)

Baylin SB, Makos M, Wu JJ, Yen RW, de Bustros A, Vertino P \& Nelkin BD 1991 Abnormal patterns of DNA methylation in human neoplasia: potential consequences for tumor progression. Cancer Cells 3 383-390.

Bills ND, Koury MJ, Clifford AJ \& Dessypris EN 1992 Ineffective hematopoiesis in folate-deficient mice. Blood 79 2273-2280.

Botez MI, Peyronnard JM, Bachevalier J \& Charron L 1978 Polyneuropathy and folate deficiency. Archives of Neurology 35 581-584. (doi:10.1001/ archneur.1978.00500330029005)

Burdge GC \& Lillycrop KA 2010 Nutrition, epigenetics, and developmental plasticity: implications for understanding human disease. Annual Review of Nutrition 30 315-339. (doi:10.1146/annurev.nutr.012809.104751)

Burren KA, Savery D, Massa V, Kok RM, Scott JM, Blom HJ, Copp AJ \& Greene ND 2008 Gene-environment interactions in the causation of neural tube defects: folate deficiency increases susceptibility conferred by loss of Pax3 function. Human Molecular Genetics 17 3675-3685. (doi:10.1093/hmg/ddn262)

George L, Mills JL, Johansson AL, Nordmark A, Olander B, Granath F \& Cnattingius S 2002 Plasma folate levels and risk of spontaneous abortion. Journal of the American Medical Association 288 1867-1873. (doi:10.1001/jama.288.15.1867)

Ghabreau L, Roux JP, Niveleau A, Fontaniere B, Mahe C, Mokni M \& Frappart L 2004 Correlation between the DNA global methylation status and progesterone receptor expression in normal endometrium, endometrioid adenocarcinoma and precursors. Virchows Archiv 445 129-134. (doi:10.1007/s00428-004-1059-4)

Ghoshal K, Li X, Datta J, Bai S, Pogribny I, Pogribny M, Huang Y, Young D \& Jacob ST 2006 A folate- and methyl-deficient diet alters the expression of DNA methyltransferases and methyl CpG binding proteins involved in epigenetic gene silencing in livers of F344 rats. Journal of Nutrition 136 1522-1527.

Hori M, Iwasaki M, Shimazaki J, Inagawa S \& Itabashi M 2000 Assessment of hypermethylated DNA in two promoter regions of the estrogen receptor alpha gene in human endometrial diseases. Gynecologic Oncology 76 89-96. (doi:10.1006/gyno.1999.5662) 
Issa JP, Ottaviano YL, Celano P, Hamilton SR, Davidson NE \& Baylin SB 1994 Methylation of the oestrogen receptor CpG island links ageing and neoplasia in human colon. Nature Genetics 7 536-540. (doi:10.1038/ ng0894-536)

Kanai Y \& Hirohashi S 2007 Alterations of DNA methylation associated with abnormalities of DNA methyltransferases in human cancers during transition from a precancerous to a malignant state. Carcinogenesis $\mathbf{2 8}$ 2434-2442. (doi:10.1093/carcin/bgm206)

Kangaspeska S, Stride B, Metivier R, Polycarpou-Schwarz M, Ibberson D, Carmouche RP, Benes V, Gannon F \& Reid G 2008 Transient cyclical methylation of promoter DNA. Nature 452 112-115. (doi:10.1038/ nature06640)

Kim YI 2005 Nutritional epigenetics: impact of folate deficiency on DNA methylation and colon cancer susceptibility. Journal of Nutrition 135 2703-2709.

Kim YI, Pogribny IP, Salomon RN, Choi SW, Smith DE, James SJ \& Mason JB 1996 Exon-specific DNA hypomethylation of the p53 gene of rat colon induced by dimethylhydrazine. Modulation by dietary folate. American Journal of Pathology 149 1129-1137.

Kotsopoulos J, Medline A, Renlund R, Sohn KJ, Martin R, Hwang SW, Lu S, Archer MC \& Kim YI 2005 Effects of dietary folate on the development and progression of mammary tumors in rats. Carcinogenesis 26 1603-1612. (doi:10.1093/carcin/bgi117)

Kotsopoulos J, Sohn KJ \& Kim YI 2008 Postweaning dietary folate deficiency provided through childhood to puberty permanently increases genomic DNA methylation in adult rat liver. Journal of Nutrition 138 703-709.

Kraunz KS, Hsiung D, McClean MD, Liu M, Osanyingbemi J, Nelson HH \& Kelsey KT 2006 Dietary folate is associated with p16(INK4A) methylation in head and neck squamous cell carcinoma. International Journal of Cancer 119 1553-1557. (doi:10.1002/ijc.22013)

Laird PW \& Jaenisch R 1996 The role of DNA methylation in cancer genetic and epigenetics. Annual Review of Genetics 30 441-464. (doi:10.1146/ annurev.genet.30.1.441)

Lapidus RG, Ferguson AT, Ottaviano YL, Parl FF, Smith HS, Weitzman SA, Baylin SB, Issa JP \& Davidson NE 1996 Methylation of estrogen and progesterone receptor gene $5^{\prime} \mathrm{CpG}$ islands correlates with lack of estrogen and progesterone receptor gene expression in breast tumors. Clinical Cancer Research 2 805-810.

Li L, Lee KM, Han W, Choi JY, Lee JY, Kang GH, Park SK, Noh DY, Yoo KY \& Kang D 2010 Estrogen and progesterone receptor status affect genomewide DNA methylation profile in breast cancer. Human Molecular Genetics 19 4273-4277. (doi:10.1093/hmg/ddq351)

Liao X, Siu MK, Chan KY, Wong ES, Ngan HY, Chan QK, Li AS, Khoo US \& Cheung AN 2008 Hypermethylation of RAS effector related genes and DNA methyltransferase 1 expression in endometrial carcinogenesis. International Journal of Cancer 123 296-302. (doi:10.1002/ijc.23494)

Logan PC, Ponnampalam AP, Rahnama F, Lobie PE \& Mitchell MD 2010 The effect of DNA methylation inhibitor 5-Aza-2'-deoxycytidine on human endometrial stromal cells. Human Reproduction 25 2859-2869. (doi:10.1093/humrep/deq238)

Lu Y, Nie J, Liu X \& Guo SW 2010 Reduced expression and concomitant promoter hypermethylation of HOXA10 in endometrium from women wearing intrauterine devices. Fertility and Sterility 94 1583-1588. (doi:10.1016/j.fertnstert.2009.09.011)

Mehrotra J, Ganpat MM, Kanaan Y, Fackler MJ, McVeigh M, LahtiDomenici J, Polyak K, Argani P, Naab T, Garrett E et al. 2004 Estrogen receptor/progesterone receptor-negative breast cancers of young African-American women have a higher frequency of methylation of multiple genes than those of Caucasian women. Clinical Cancer Research 10 2052-2057. (doi:10.1158/1078-0432.CCR-03-0514)

Metivier R, Gallais R, Tiffoche C, Le Peron C, Jurkowska RZ, Carmouche RP, Ibberson D, Barath P, Demay F, Reid G et al. 2008 Cyclical DNA methylation of a transcriptionally active promoter. Nature 452 45-50. (doi:10.1038/nature06544)

Morey Kinney SR, Smiraglia DJ, James SR, Moser MT, Foster BA \& Karpf AR 2008 Stage-specific alterations of DNA methyltransferase expression, DNA hypermethylation, and DNA hypomethylation during prostate cancer progression in the transgenic adenocarcinoma of mouse prostate model. Molecular Cancer Research 6 1365-1374. (doi:10.1158/15417786.MCR-08-0040)
Munro SK, Farquhar CM, Mitchell MD \& Ponnampalam AP 2010 Epigenetic regulation of endometrium during the menstrual cycle. Molecular Human Reproduction 16 297-310. (doi:10.1093/molehr/ gaq010)

Okano M, Bell DW, Haber DA \& Li E 1999 DNA methyltransferases Dnmt3a and Dnmt3b are essential for de novo methylation and mammalian development. Cell 99 247-257. (doi:10.1016/S00928674(00)81656-6)

Oommen AM, Griffin JB, Sarath G \& Zempleni J 2005 Roles for nutrients in epigenetic events. Journal of Nutritional Biochemistry 16 74-77. (doi:10.1016/j.jnutbio.2004.08.004)

Paria BC, Huet-Hudson YM \& Dey SK 1993 Blastocyst's state of activity determines the "window" of implantation in the receptive mouse uterus. PNAS 90 10159-10162. (doi:10.1073/pnas.90.21.10159)

Patring JD, Jastrebova JA, Hjortmo SB, Andlid TA \& Jagerstad IM 2005 Development of a simplified method for the determination of folates in baker's yeast by HPLC with ultraviolet and fluorescence detection. Journal of Agricultural and Food Chemistry 53 2406-2411. (doi:10.1021/ jf048083g)

Piva R, Kumar VL, Hanau S, Rimondi AP, Pansini S, Mollica G \& del Senno L 1989 Abnormal methylation of estrogen receptor gene and reduced estrogen receptor RNA levels in human endometrial carcinomas. Journal of Steroid Biochemistry 32 1-4. (doi:10.1016/00224731(89)90005-8)

Piyathilake CJ, Celedonio JE, Macaluso M, Bell WC, Azrad M \& Grizzle WE 2008 Mandatory fortification with folic acid in the United States is associated with increased expression of DNA methyltransferase-1 in the cervix. Nutrition 24 94-99. (doi:10.1016/j.nut.2007.10.007)

Pogribny IP \& James SJ 2002 De novo methylation of the p16INK4A gene in early preneoplastic liver and tumors induced by folate/methyl deficiency in rats. Cancer Letters 187 69-75. (doi:10.1016/S0304-3835 (02)00408-1)

Rahnama F, Thompson B, Steiner M, Shafiei F, Lobie PE \& Mitchell MD 2009 Epigenetic regulation of $\mathrm{E}$-cadherin controls endometrial receptivity. Endocrinology 150 1466-1472. (doi:10.1210/en.2008-1142)

Ren Y, Liu X, Ma D, Feng Y \& Zhong N 2007 Down-regulation of the progesterone receptor by the methylation of progesterone receptor gene in endometrial cancer cells. Cancer Genetics and Cytogenetics 175 107-116. (doi:10.1016/j.cancergencyto.2007.02.002)

Robert MF, Morin S, Beaulieu N, Gauthier F, Chute IC, Barsalou A \& MacLeod AR 2003 DNMT1 is required to maintain CpG methylation and aberrant gene silencing in human cancer cells. Nature Genetics 33 61-65. (doi:10.1038/ng1068)

Ronnenberg AG, Venners SA, Xu X, Chen C, Wang L, Guang W, Huang A \& Wang X 2007 Preconception B-vitamin and homocysteine status, conception, and early pregnancy loss. American Journal of Epidemiology 166 304-312. (doi:10.1093/aje/kwm078)

Sutterlin M, Bussen S, Ruppert D \& Steck T 1997 Serum levels of folate and cobalamin in women with recurrent spontaneous abortion. Human Reproduction 12 2292-2296. (doi:10.1093/humrep/12.10.2292)

Suzuki F, Akahira J, Miura I, Suzuki T, Ito K, Hayashi S, Sasano H \& Yaegashi $\mathbf{N} 2008$ Loss of estrogen receptor beta isoform expression and its correlation with aberrant DNA methylation of the $5^{\prime}$-untranslated region in human epithelial ovarian carcinoma. Cancer Science 99 2365-2372. (doi:10.1111/j.1349-7006.2008.00988.x)

Teperek-Tkacz M, Pasque V, Gentsch G \& Ferguson-Smith AC 2011 Epigenetic reprogramming: is deamination key to active DNA demethylation? Reproduction 142 621-632. (doi:10.1530/REP-11-0148)

Tseng LH, Chen I, Chen MY, Yan H, Wang CN \& Lee CL 2010 Genomebased expression profiling as a single standardized microarray platform for the diagnosis of endometrial disorder: an array of 126-gene model. Fertility and Sterility 94 114-119. (doi:10.1016/j.fertnstert.2009.01.130)

Vincent ZL, Farquhar CM, Mitchell MD \& Ponnampalam AP 2011 Expression and regulation of DNA methyltransferases in human endometrium. Fertility and Sterility 95 1522-1525. (doi:10.1016/ j.fertnstert.2010.09.030)

Walzem RL \& Clifford AJ 1988 Folate deficiency in rats fed diets containing free amino acids or intact proteins. Journal of Nutrition 118 1089-1096.

Wang H \& Dey SK 2006 Roadmap to embryo implantation: clues from mouse models. Nature Reviews. Genetics 7 185-199. (doi:10.1038/ nrg1808) 
Wasson GR, McGlynn AP, McNulty H, O'Reilly SL, McKelvey-Martin VJ, McKerr G, Strain JJ, Scott J \& Downes CS 2006 Global DNA and p53 region-specific hypomethylation in human colonic cells is induced by folate depletion and reversed by folate supplementation. Journal of Nutrition 136 2748-2753.

Wei J, Han B, Mao XY, Wei MJ, Yao F \& Jin F 2012 Promoter methylation status and expression of estrogen receptor alpha in familial breast cancer patients. Tumor Biology 33 413-420. (doi:10.1007/s13277-011-0234-x)

Xue Q, Lin Z, Cheng YH, Huang CC, Marsh E, Yin P, Milad MP, Confino E, Reierstad S, Innes J et al. 2007 Promoter methylation regulates estrogen receptor 2 in human endometrium and endometriosis. Biology of Reproduction 77 681-687. (doi:10.1095/biolreprod.107.061804)
Yamagata Y, Asada H, Tamura I, Lee L, Maekawa R, Taniguchi K, Taketani T, Matsuoka A, Tamura H \& Sugino N 2009 DNA methyltransferase expression in the human endometrium: down-regulation by progesterone and estrogen. Human Reproduction 24 1126-1132. (doi:10.1093/humrep/dep015)

Received 5 January 2012

First decision 2 February 2012

Revised manuscript received 2 May 2012

Accepted 10 May 2012 